UDC 532.5

V. Filonov,

Y. Dubyk, PhD,

K. Lukianenko

"IPP-Centre” LLC, 8 Bolsunovska Str., Kyiv, Ukraine, 01014; e-mail: workfvv@gmail.com

\title{
ESTIMATION OF MCP-195M ELEMENTS STRESS-STRAIN STATE AT THE INITIAL DYNAMICS OF SHAFT JAMMING/MPA TRANSIENT PROCESS
}

В.В. Філонов, Я.Р Дубик., К.М. Лук'яненко. Оцінка НДС елементів ГЦН-195М при початковій динаміці перехідного процесу заклинювання валу/МПА. ГЦН $є$ важливим елементом для безпечної експлуатації АЕС. В процесі обгрунтування можливості продовження ресурсу обладнання вітчизняних енергоблоків окрема увага приділяється оцінці стану корпусу ГЦН. Насамперед, це пов'язано з тим, що корпус насосу виконує функцію бар'єру безпеки, а також є важко змінним елементом РУ. Цілісність елементів ГЦН оцінюється для багатьох представницьких аварійних сценаріїв, які розраховуються за допомогою системних теплогідравлічних кодів типу RELAP/КОРСАР. В кращому випадку, в таких кодах насосний агрегат може бути представлений моделлю інерційної ланки першого порядку, що дає можливість імітувати його вибіг. Проте, такі моделі принципово не можуть відтворювати поведінку ГЦН при миттєвій зміні крутного моменту, а також при ударній зміні абсолютного тиску. Це, фактично, призводить до невизначеності відносно початкової динаміки при таких перехідних процесах, що може вплинути на якісні та кількісні характеристики процесів. Фактично, результати, які отримуються за допомогою нодальних теплогідравлічних кодів $є$ безвідносними, тобто, не зрозуміло чи вони недооцінюють чи переоцінюють важливі для подальших міцнісних розрахунків термічні параметри. В роботі представлено спрощені CFD- та CAE-моделі ГЦН-195М для аналізу початкової динаміки перехідного процесу при його заклинюванні. Існує невизначеність стосовно абсолютного значення амплітуди динамічних навантажень при заклинюванні валу ГЦН, також залишається незрозумілим, до якої групи явищ слід відносити даний процес та наскільки врахування його $є$ критичним при продовжені ресурсу елементів насосу. Розроблена CFD-модель, яка включає в себе об'єм теплоносія та САЕ-модель елементів конструкції ГЦН, що утворюють однонаправлений інтерфейс взаємодії рідини та конструкції. CFD-модель була валідована на предмет повторення експериментальних характеристик насосу. Для аналізу перехідного процесу в проточній частині ГЦН було використано «метод стисливої рідини», який попередньо перевірений на коректність прогнозування характеристик класичного гідроудару. Результати подальшого аналізу НДС елементів ГЦН свідчать про відсутність критичних напружень 3 точки зору міцності конструкцій. Отримані за допомогою CFD, амплітуди зміни тиску для початкової динаміки розглянутих процесів (здебільшого МПА) можуть бути використані в якості коригуючих функцій для моделі насосу в системних теплогідравлічних кодах.

Ключові слова: CFD-моделювання, ГЦН, робоче колесо, перехідний процес, оцінка міцності, МПА, САЕ-модель

V. Filonov, Y. Dubyk, K. Lukianenko. Estimation of MCP-195M elements stress-strain state at the initialdinamics of shaft jamming/MPA transient process. MCP is an important element for NPPs safe operation. During the lifetime prolongation project for domestic power units, special attention is paid to assessment of MCPs body state. First, this is because pump body serves as a safety barrier, and that it is a hard-replaceable NPP element. The MCP elements integrity is estimated for many representative emergency transients, which are calculated using system thermal hydraulics codes (RELAP/CORSAR). In the best case, in such codes the pump unit can be represented by first order inertial link model, which makes it possible to simulate its run-out. However, such models cannot fundamentally reproduce MCP dynamic during the instantaneous change in torque, as well as during shock changes in absolute pressure. This actually leads to uncertainties of initial dynamics for such transients that can effect on their qualitative and quantitative characteristics. In fact, obtained by nodal thermal hydraulic codes results are irrelevant, i.e. it is unclear whether they underestimate or overestimate thermal parameters important for future strength calculations. This work presents simplified CFD-models and CAE-models of MCP-195M for analysis of transient process with pump jamming initial dynamics. There is an uncertainty regarding the absolute value of dynamic loads amplitude when pump shaft is jamming. It is also incomprehensible to which phenomena group we should refer this process, and is taking account of it phenomena due prolongation of MCP elements service life is critical. Developed CFD-model includes coolant domain and CAE-model of MCP construction elements, which create a unidirectional fluid - solid interaction interface. CFD-model was validated for a correspondence with experimental pump characteristics. For analysis of transient process in flow MCP part "compressible liquid method" was used. Initially, this method was tested for correct prediction of classical water hammer characteristics. Stress assessment of MCP elements indicates that strength criterions are satisfied. Pressure change amplitudes obtained using CFD for initial dynamics of considered processes (mostly BLOCA) could be used as corrective functions for pump model in system thermal hydraulic codes.

Keywords: CFD-simulation, MCP, impeller, transient process, strength assessment, BLOCA, CAE-model

Introduction. System one-dimensional / pseudo-three-dimensional thermal-hydraulic codes of RELAP/CORSAIR type are not capable to predict correctly the differential characteristics that deter-

DOI: 10.15276/opu.3.59.2019.04

(C) 2019 The Authors. This is an open access article under the CC BY license (http://creativecommons.org/licenses/by/4.0/). 
mine structural integrity of equipment. The use of CFD, together with system codes, allows us to obtain in-depth simplified and limited in width optimal computational models capable to predict fundamentally three-dimensional processes. Analysis of these processes is very important for the formation of realistic boundary conditions (BC) and to further assessment the residual life of the NPP equipment.

In terms of impact on the reliability of the main elements of the circulation pump (MCP), one of the most dangerous processes is the shaft jamming. In this case, the transient process of global restructuring of the flow with the redistribution of energy evolves over several tens of milliseconds. After jamming of the MCP, due to changes in the direction of the meridional component of absolute velocity, additional abrupt short-term dynamic loads on the working blades may occur. The flow part of the MCP-195M is made to ensure the passage of the coolant, regardless of the orientation of the impeller, provided the integrity of all elements. This ensures no hydraulic shock, and the main pressure rise is caused by the transition of kinetic energy of the stream into the potential energy of the fluid. At the edges of the working blades, hypothetically, there may be a flow disruption and the origin of the cavitation process. The most dangerous, in terms of dynamic impact on the MCP elements, is the transient process caused by the circulation loop rupture. In this case, called maximum project accident (MPA), the dynamics of the process, is determined by time, several times greater than the dynamics of MCP shaft jamming.

Analysis of recent publications and problem statement. Hypothetically, with the partial overlap of the cross-section of the flow portion of the blades or outlet pipe, incomplete hydraulic shock of the maximum amplitude of $1 \mathrm{MPa}$ can occur during MCP shaft jamming [1]. Phenomenology of the MCP shaft jamming process or the MPA dynamics has not been practically studied. Therefore, it is important to develop models based on three-dimensional calculated hydrodynamics, which will allow to evaluate the dynamic response of the flowing part of the MCP and to formulate correct boundary conditions for further strength analysis.

The purpose and objectives of the study. The purpose of the three-dimensional MCP-195M CFD model is to determine the risk of pump elements being affected by the initial transient dynamics due to a sharp drop in torque or absolute pressure.

Creating a calculation model. The main complexity of the development of the MCP-195M CFD-model is caused by the geometric uncertainty of the pump impeller, which can lead to a mismatch with the experimental head pressure.

The design model includes the pump impeller coolant space and outlet device, as well as the inlet and outlet pipelines. The general view of the calculation model is shown in Fig. 1.

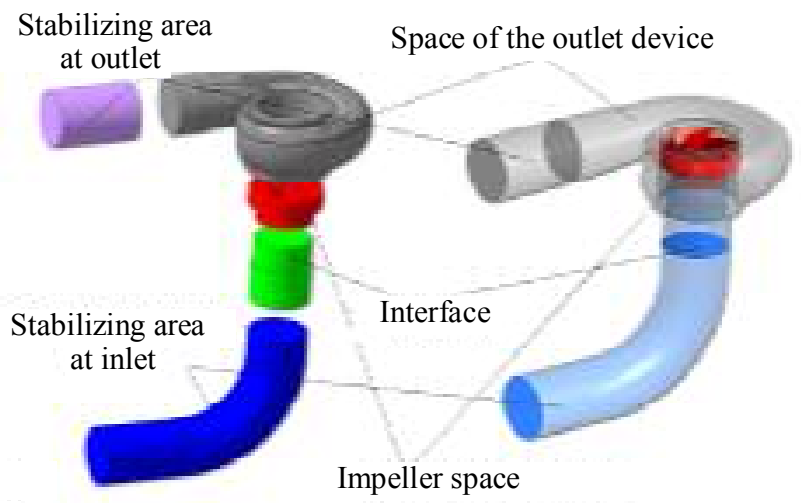

$a$

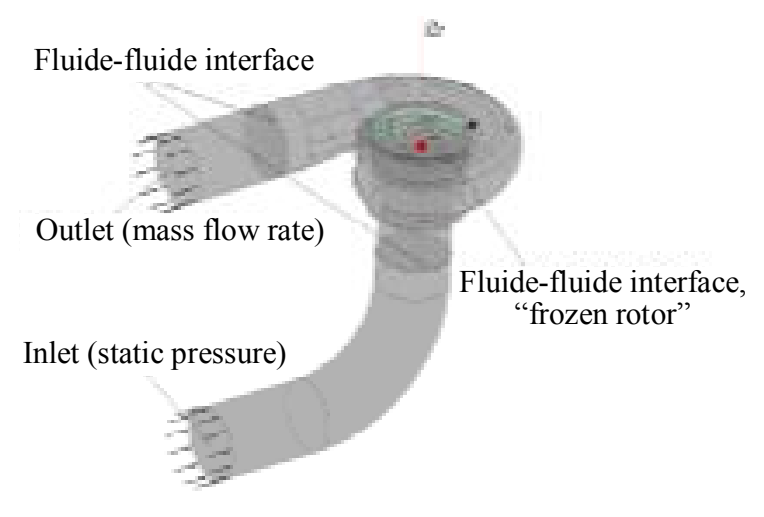

$b$

Fig. 1. General view of the calculation model: components (a), boundary conditions (b)

To evaluate the characteristics of the initial dynamics for the MCP shaft jamming or breaking the circulation loop using CFD analysis, a model of the flowing part of the MCP-195M was developed. Assuming that during velocity field volume changed, as well as in the case of pressure surge, there are 
no cavitation processes, then the ability of the CFD codes to predict the dynamics of the transient for the MCP depends on the quality of the direct / indirect water hammer modeling as well as rotating flow modeling. Implementation of a direct water hammer in the MCP is possible only hypothetically. However, this phenomenon is the most difficult in terms of CFD. Modeling the dynamic impact on the wall requires consideration of the compressibility of the coolant, which is formulated on the basis of the Tate equation (compressible fluid method) [2]. The application of this dependence on the example of direct water hammer analysis is demonstrated in [3].

Spatial sampling of the calculation model is based on a hybrid approach. In the first stage, based on the semi-empirical boundary layer theory [4] and the experience of modeling different blade machines [5], the parameters of the discrete analogue of the boundary layer were evaluated. In the second stage, varying the spatial sampling density, variant calculations were performed to analyze the results of mesh convergence [6]. The general view of the calculation grid and the graph of the convergence results are shown in Fig. 2. The following characteristic values were selected for mesh convergence analysis: coolant pressure, efficiency, average speed and static pressure at the outlet of the impeller.
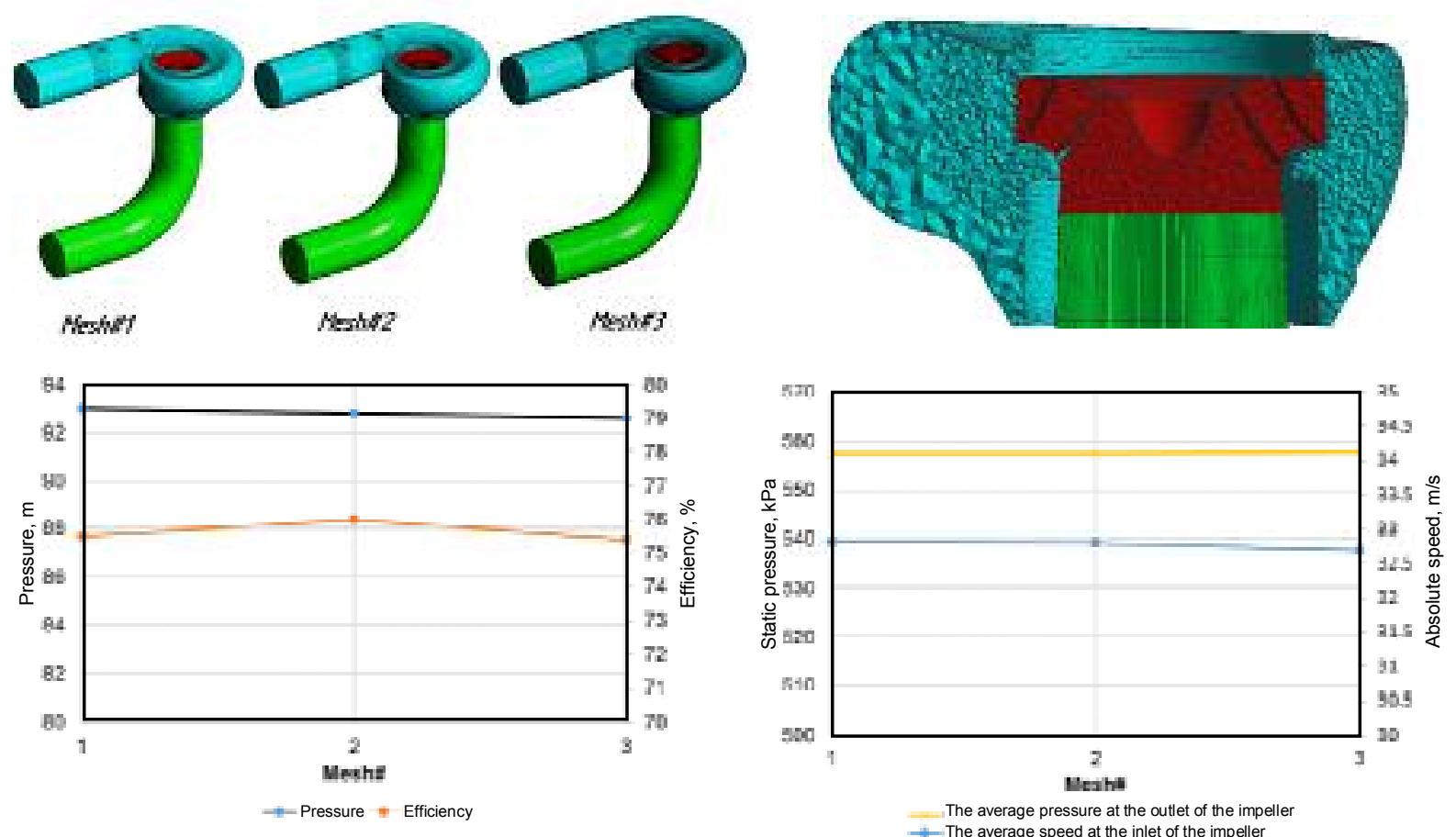

Fig. 2. General view of the calculation grid and the results of convergence analysis

As is known from the theory of blade machines [7], the pump head can be determined according to the following relationship:

$$
H=\frac{1}{\rho g}\left(P_{\text {out }}-P_{\text {in }}\right)+\frac{1}{g}\left(\frac{C_{\text {out }}^{2}}{2}-\frac{C_{\text {in }}^{2}}{2}\right),
$$

where $P_{\text {out }}, P_{\text {in }}$ - static pressure at the outlet and inlet respectively;

$C_{\text {out }}, C_{\text {in }}$ - absolute output and inlet speeds;

$\rho$ - average coolant density;

$g$ - acceleration of free fall.

The efficiency of the pump unit can be found by dependence $(2)[5,7]$. 


$$
\eta=\frac{Q \cdot \rho g H}{\int_{0}^{\pi n / 30} M_{o z} d \omega},
$$

where $M_{o z}$ - torque relative to the axis of rotation of the impeller.

Variant calculations were performed for the nominal mode of the MCP operation. The coolant flow rate was taken to be $4000 \mathrm{~kg} / \mathrm{s}$, at a temperature of $300^{\circ} \mathrm{C}$.

Subsequent calculations used mesh \# 1 and mesh \# 2 containing 1.8 and 4.1 million control volumes, respectively. Mesh \# 1 was used to calculate the pressure characteristics, mesh \# 2, respectively, for the analysis of dynamic response. The calculation of the head pressure characteristic of MCP$195 \mathrm{M}$ in comparison with the tests [8], as well as the 4 quadrant dependence is shown in Fig. 3, $a$. There is a rotational flow around the axis of the pressure head of the MCP, which is consistent with the analysis [9].

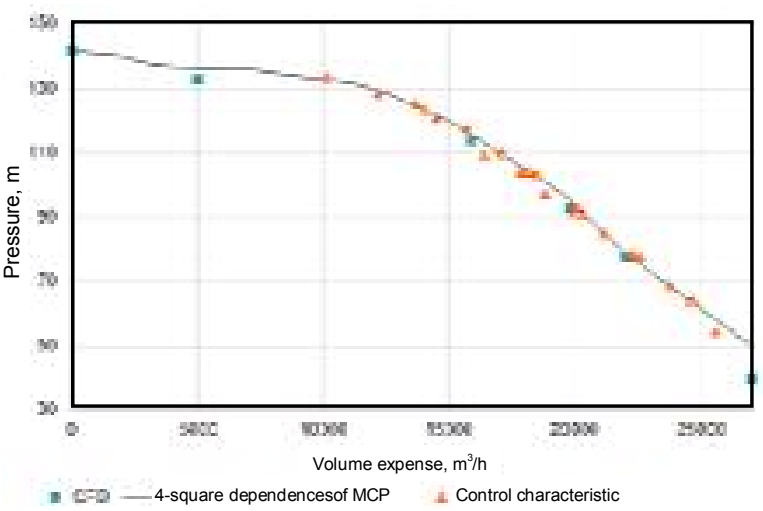

$a$

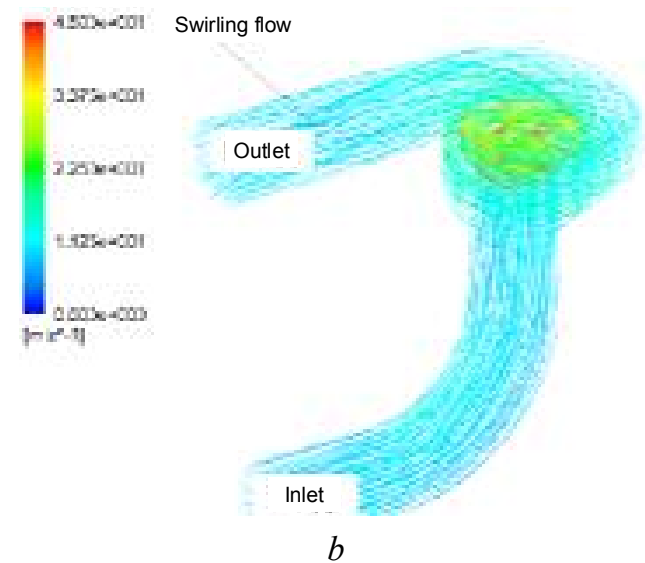

Fig. 3. Results of a series of steady-state calculations: results of verification of the pressure characteristic(a), demonstration of a twisted current line in the output branch pipe (b)

The calculation points agree well with the test curve and maximum deviation not exceeding $5 \%$. The operating point of the pump, at the reactor normal operation, is as follows: head $-92.7 / 92 \mathrm{~m}$, efficiency $-76.1 / 76.7 \%$, power $-4.88 / 4.91 \mathrm{MW}$. This suggests that transients associated with a change in network characteristic (MPA) or, directly, with a change in torque (jamming of the MCP shaft), can be adequately predicted by the model developed in the case of a single-phase environment.

Analysis of initial dynamics for the MCP-195M shaft jamming. For this type of modeling, it is considered that the angular velocity changes abruptly from the nominal value to zero. In this case, the dynamic impact was considered for two cases. In the first case, due to the inertia of the flow, the mass flow rate of the coolant practically does not change within one period of the rotating pressure wave. This approach is consistent with the mass boundary condition at the inlet and the "open boundary" at the outlet. In the second case, the "open boundary" corresponds to the inlet and outlet, which makes it possible to take into account the energy loss in both directions of the pipeline, which probably reduces the dynamic impact.

The analysis was divided into two stages:

- Modeling of the steady state operation of the MCP at the nominal parameters of the reactor unit (NO) operation using the "compressible fluid" method.

- Simulation of a non-stationary flow process in the flowing part with a sharp change in the angular velocity to zero.

The calculation was performed on mesh \# 2 calculation grid (see Fig. 2). The stationary calculation was performed using the combined time step settings for the pseudo-stationary process characteristic of ANSYS CFX. The global imbalance of calculations at each time step does not exceed $1 \%$. Estimated time step is $0.0005 \mathrm{sec}$. within $0.0045 \mathrm{~s}$. 
After MCP shaft jamming, the average static pressure in the flowing part of the pump is almost instantaneously reduced due to the lack of flow energy gain from the working blades. In this case, on the inner surface of the MCP housing along the wave front, there is a region of compression of the coolant and, thus, an increase in static pressure due to the inhibition of the directional movement of the coolant, which inertialy moves from the space between the blades. Therefore, the magnitude that characterizes the dynamic effect is the difference between the maximum and the average volume of pressure. For the first few milliseconds, the processes with one and two "open boundaries" are almost identical (Figs. 4, 5). After the pressure wave from the pressure head reaches the inlet nozzle, the mass flow rate is no longer constant. In the first case, the presence of a constant action of the head of the coolant at the inlet leads to the fact that part of the wave energy is stored in the fluid space, which leads to damping oscillations. A characteristic difference of damped oscillations with one "open boundary", compared to two "open boundaries", is the presence of greater relaxation of oscillations in the second case (more than $95 \%$ of the amplitude damping in one period). Thus, in terms of initial impact, both approaches are equivalent. If we consider the development of the process, the most plausible is the option with two "open borders". In addition, in this case, in the future there is an opportunity to take into account the support from the side of the MCP, which leads to a more severe change in the flow of coolant through the flow part.
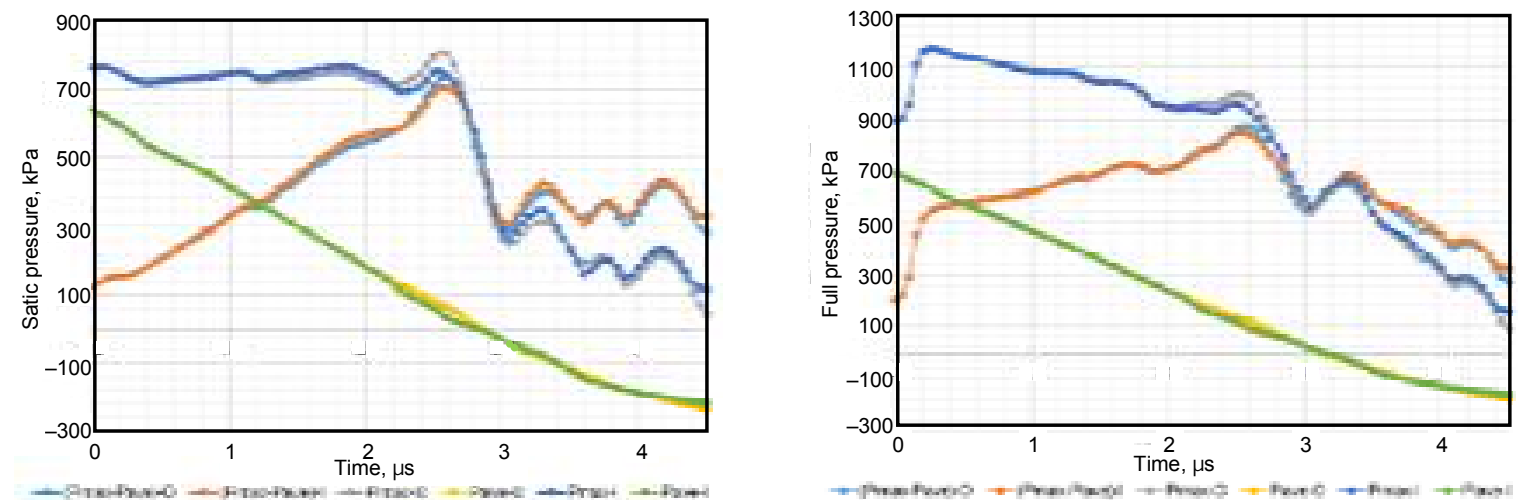

Fig. 4. Dynamics of change of static and full pressure on the inner surface of the outlet device (I - "opening" boundary condition at the outlet, $O$ - "opening" BC's at the inlet and outlet)

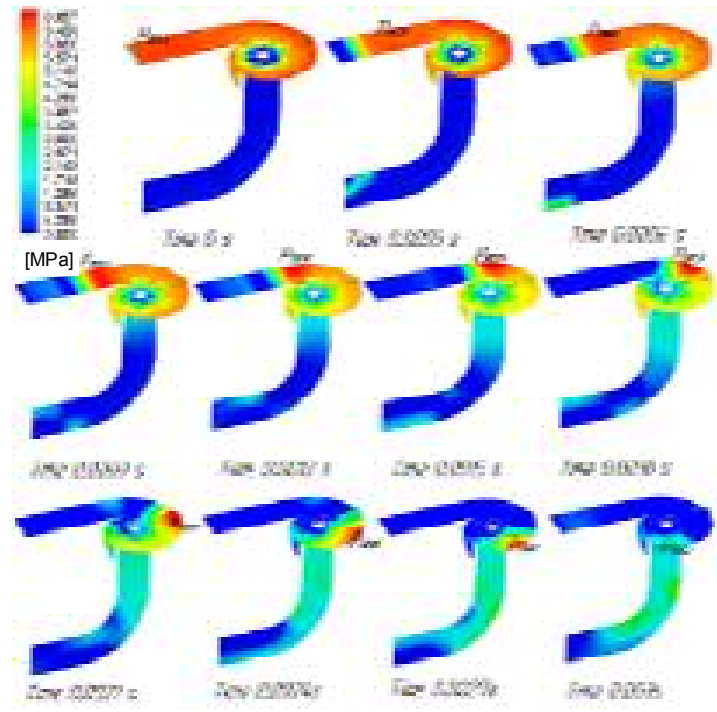

$a$

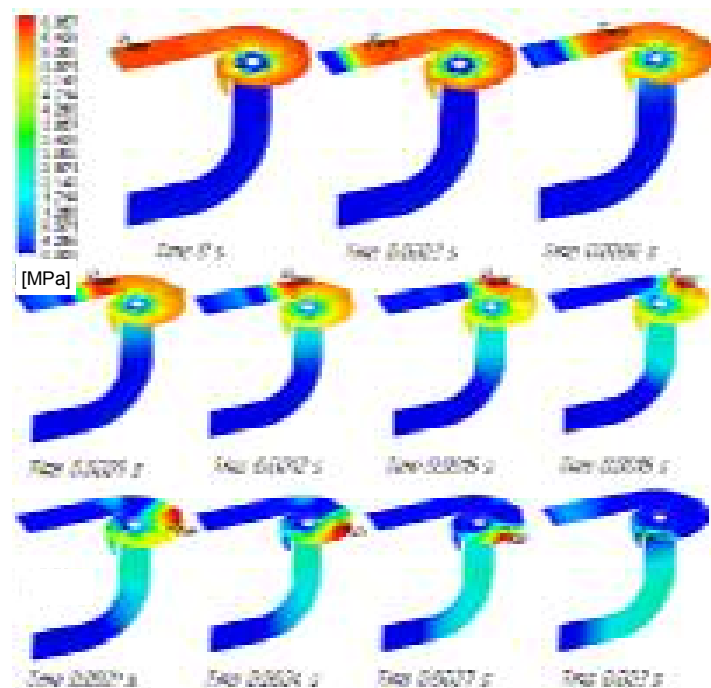

$b$

Fig. 5. Dynamics of rotational pressure wave motion (relative value): "opening” boundary condition at the outlet (a), "opening" BC's at the inlet and outlet (b) 
Analysis of the dynamic influence of the coolant at the instantaneous MCP shaft jamming indicates the absence of water hammer. The main influence on the internal surface of the outlet of the MCP is the rotating wave caused by the tuning flow. In the first few milliseconds, the average static pressure of the coolant rapidly drops, which, during the development of the process, fluctuates around the conditional zero (in the calculations, the conditional zero is $15.78 \mathrm{MPa}$ ). In this case, the value of the maximum pressure practically does not change and moves clockwise until the wave reaches the inlet. The failure of the mean pressure volume (at constant maximum) can be interpreted as an increase in static pressure relative to the constant mean value. Then, the amplitude of the conditional incomplete water hammer is $0.7 \mathrm{MPa}$, and the similar value of the total pressure is $0.85 \mathrm{MPa}$.

In the subsequent strength analysis, we use the results obtained for the two-open-bound variant in the form of a distributed absolute pressure value under the boundary conditions of the CAE models of the MCP elements.

Analysis of initial dynamics at the maximum project accident (MPA). Thermal-hydraulic analysis of the leakage of a coolant into the space of a containment shell at MPA has a number of uncertainties $[10,11]$ :

- Quasi-static pressure in the output section of the coolant leak.

- Impact of steam plug.

- Effect of a two-phase medium on the propagation of a shock wave of pressure.

- Availability of working MCP and their effect on the flow restructuring, as well as the resistance of the circuit to the propagation of the shock wave from the MCP input / output branch.

The developed CFD-model of MCP-195M gives an opportunity to evaluate the process characteristics in a single-phase formulation and is the first approximation in the analysis of the response to the rupture of the circulation circuit. Dynamics in shocks and sudden changes in shut-off pressure (taking into account the current crisis) are in most cases adequately predicted in a one-dimensional approximation and, in many cases, the preferred approach. The rate of coolant leakage is a major factor in the dynamic impact on the MCP. The limiting factor for the rate of coolant leakage, with the existing pressure drop, is the local speed of sound in the environment. In the case of two-phase flow, the speed of sound is substantially lower than in the liquid and, even, in the vapor phase. In a single-phase environment, a flow crisis occurs at a much higher mass flow rate, which results in higher loads on the supports and pump outlet. Evaluation for a single-phase environment that eliminates the possibility of cavitation is considered to be a more conservative option, although this statement is not conclusive and possibly unfair to the impeller.

To form a boundary condition that corresponds to the rupture of the circulation loop, it is necessary to determine the shut-off pressure. Because we analyze the short-term, the impact of the increase in pressure in the feed is neglected. To estimate the pressure drop during the depressurization of the hot water circuit, an additional calculation procedure was created that takes into account the additional saturation pressure. However, from a thermophysical point of view, the saturation pressure is considered quasi-stable. The nucleation effect is evaluated by an additional procedure. The phenomenological and mathematical foundations of this effect have been implemented in accordance with the experimental and theoretical generalizations described in $[12,13]$. The use of additional shut-off pressure estimation is necessary in the case of a detailed shock wave analysis over several periods.

In [3] the problem of propagation of the decompression wave upon breaking of the cold loop of the main circulation pipeline (MCP) in the WWER-1000 reactor under identical boundary conditions 
is considered. On the basis of the results obtained in [3], boundary conditions on the inlet branch in the MCP were formulated (Fig. 6), which partially account for the development of decompression waves through a reactor, which in the first approximation corresponds to their system interconnection. Thus, two variants of boundary conditions are considered. In the first case, the "open boundary" on the inlet nozzle with a shut-off pressure of $15.78 \mathrm{MPa}$ is considered. In the second case, the shut-off pressure obtained at the reactor outlet in the analysis of the maximum project accident (MPA) [3] is considered. In both cases, "open boundary" condition is used with a decompression shut-off pressure (Fig. 5). The initial pressure point $\left(20000 \mathrm{~m}^{3} ; 92 \mathrm{~m}\right)$ was selected as the initial condition. The time step of the calculation was $0.001 \mathrm{sec}$, which gradually increased to $0.0025 \mathrm{sec}$. All other parameters are similar to the calculations of the MCP shaft jamming.

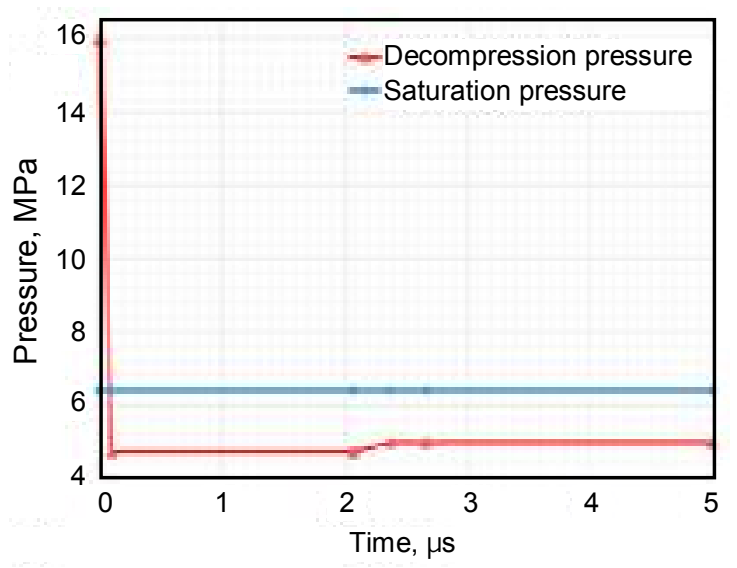

$a$

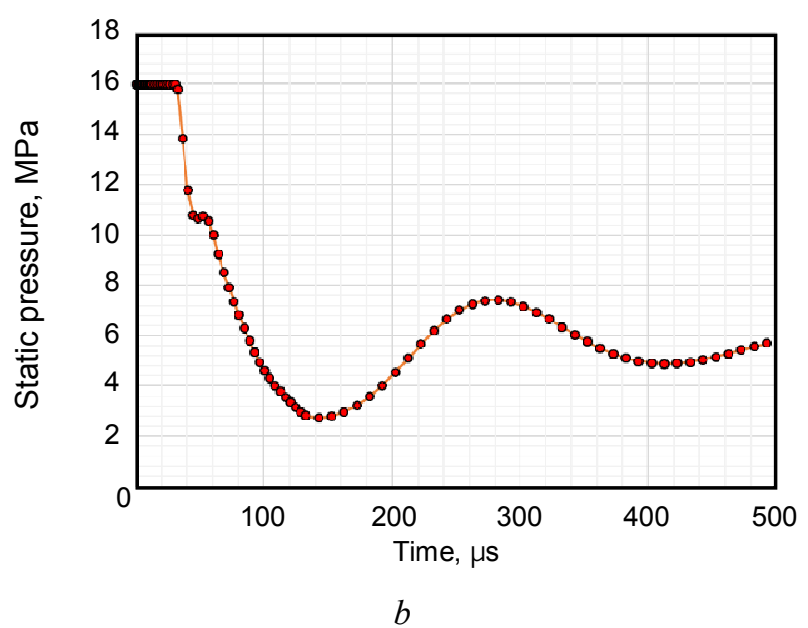

Fig. 6. Boundary conditions at the inlet and outlet ports of the MCP; decompression (a), at the inlet with allowance for the reactor (b)

The reactive force acting on the MCP was estimated according to the Mescherskii dependence in which the displacement of the pump goes to zero. Then, the reactive force is reduced to a simple ratio:

$$
m \frac{d^{1}}{d t}=\stackrel{\mathrm{r}}{F}+\frac{d m}{d t} \stackrel{\mathrm{r}}{W} \Rightarrow F=G W
$$

where $F$ - reactive power;

$G$ - mass flow rate of coolant;

$W$ - the velocity of the coolant in the output section.

The results of a simplified analysis of the transient process in the breakdown of the MCP indicate that, from the hydrodynamic point of view (notwithstanding the initial amplitude of $5 \ldots 6 \mathrm{MPa}$ ), there is no critical force on the MCP outlet, as well as on the hydraulic shock absorbers. Probably the greatest danger this process poses to the pump impeller. The results of the calculations for the two variants of the boundary conditions are shown in Fig. 7. 


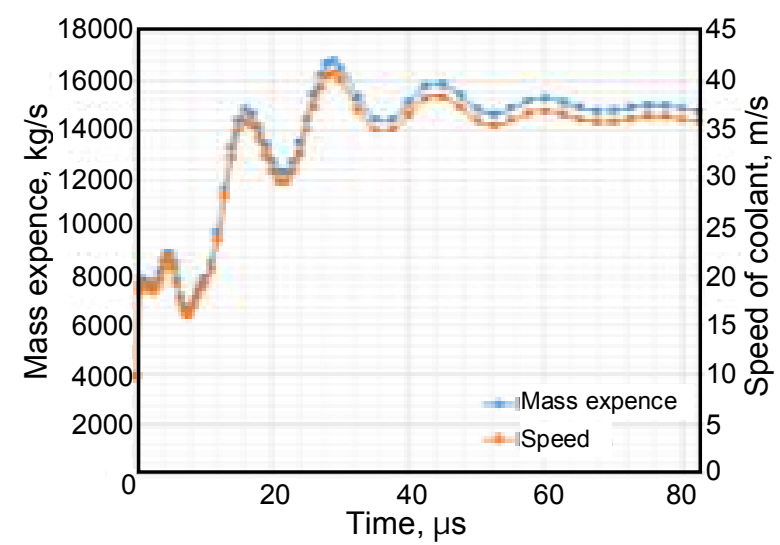

$a$

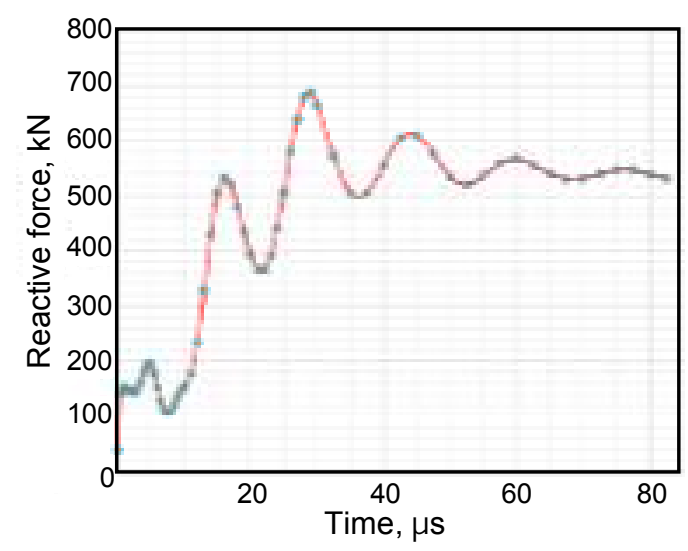

$b$

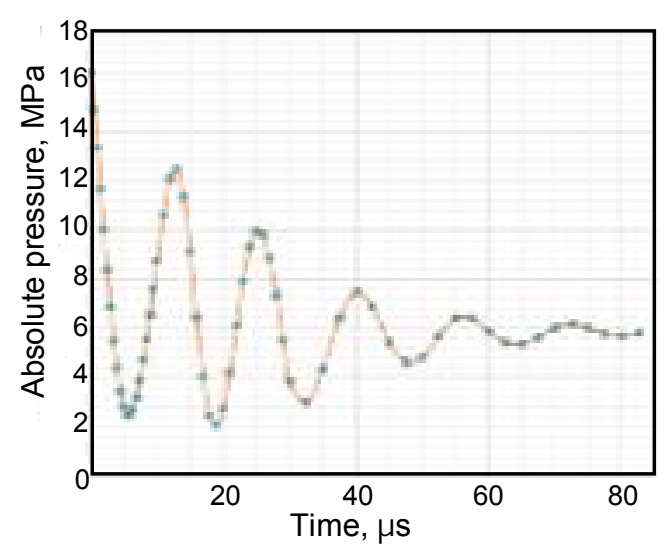

$c$

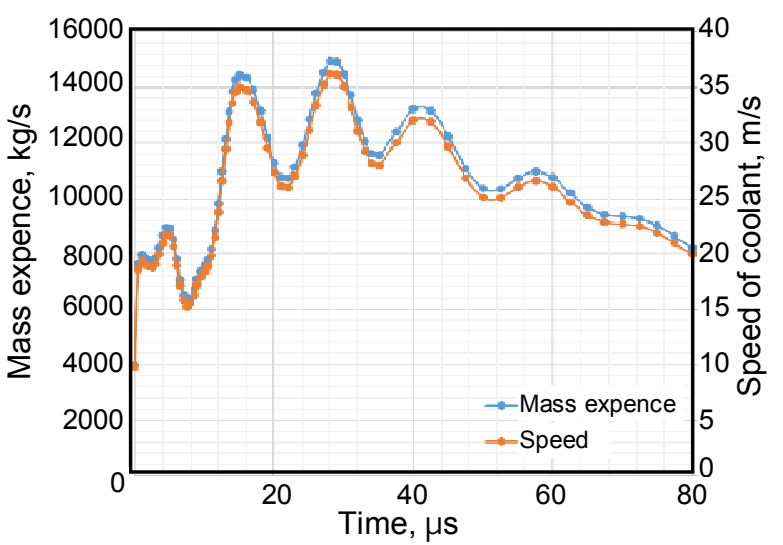

$a(p)$

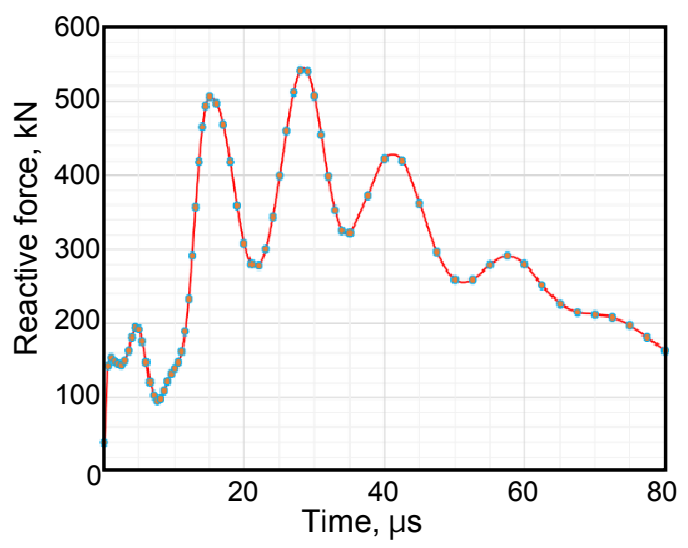

$b(p)$

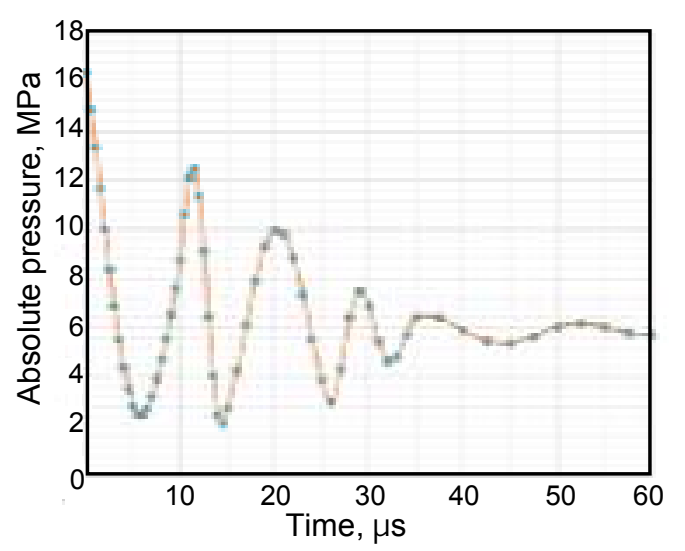

$c(p)$

Fig. 7. Calculation results: change of mass flow rate and velocity of the coolant in the output section of the pressure head of the MCP (a), change of the reactive force in time (b), change of the absolute pressure averaged over the surface of the discharge device of $M C P(c),(p-b o u n d a r y$ conditions taking into account the reactor)

For each of the two variants of the $\mathrm{BC}$ formation, the initial change in absolute pressure and velocity field is qualitatively identical (Fig. 8). 

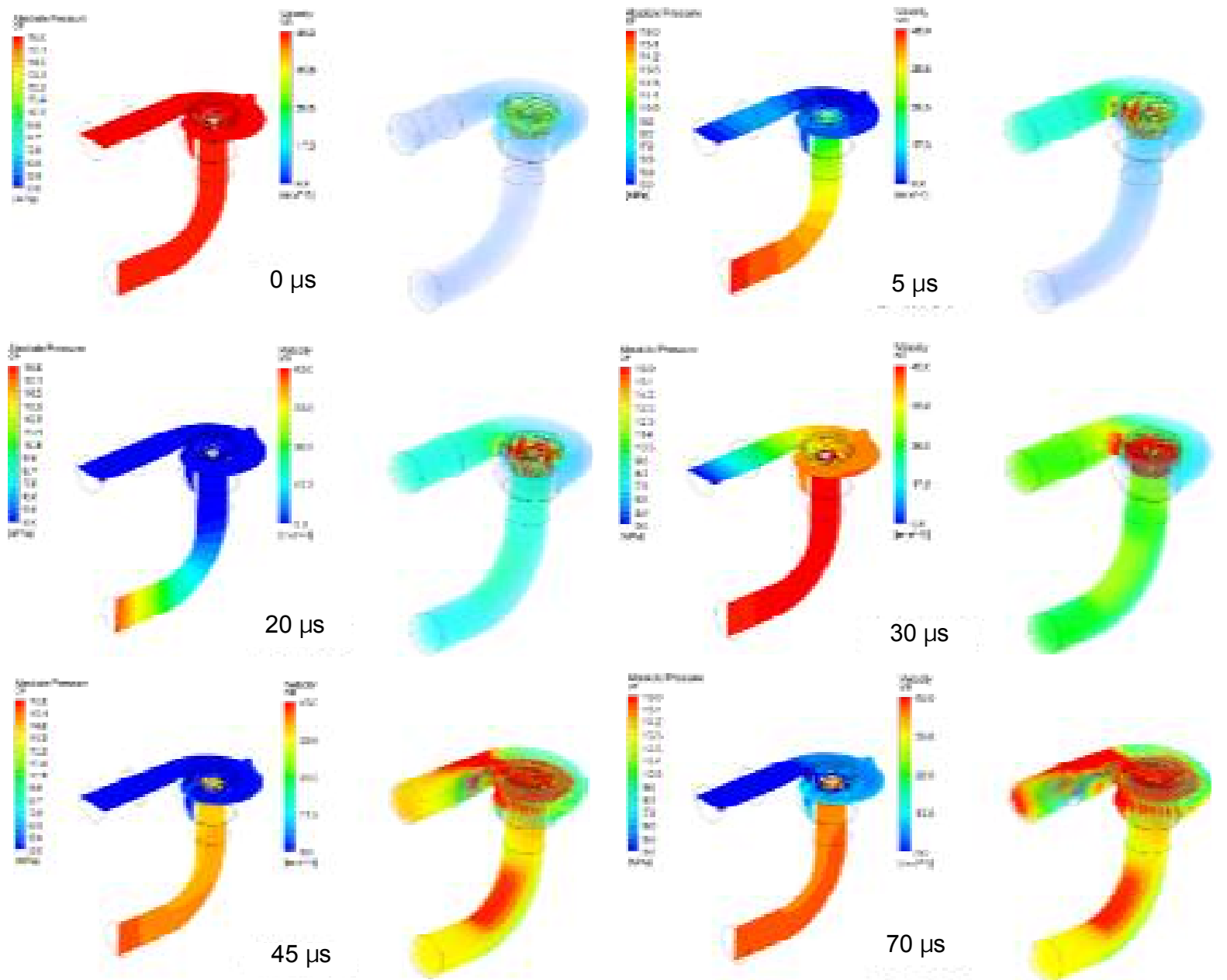

Fig. 8. Initial dynamics of change in absolute pressure and velocity at rupture of the cold circulating loop of the $M C P$

Subsequently, on the basis of the obtained results, spatially dependent boundary conditions for CAE-models of the MCP elements were formed to estimate the stress-strain state.

Estimation of strength of MCP elements under dynamic influences. From the structural integrity point of view, MPA and shaft jamming, they are the most dynamic accidents, which are insufficiently evaluated using system codes, in particular RELAP. During these accidents, the following elements are most affected by the dynamic loads: the MCP housing, the supporting elements (including hydro shock absorbers), the blades and the shaft. If the body and support elements have evaluation criteria and strength requirements [14], the situation with the shaft and blades is somewhat uncertain. Firstly, there are no regulatory documents for assessing these dynamic phenomena from the strength point of view and secondly, should the strength conditions be fulfilled for them at all? Their fail will not lead to breaches of safety barriers. It is also quite clear that after the MPA the reactor should not be operated. In addition, after stopping, the MCP internal units can be inspected and replaced. On the other hand, failure of the blades, for example, can cause active zone damage by foreign object, which is undesirable in any case. Therefore, in order to ensure reliable operation of the power unit, during the over-design period the fulfillment of the conditions of durability of the MCP housing and supporting elements is a mandatory requirement, and for blades and shaft is an additional requirement.

Pump housing is massive injection molding piece that is designed with a large margin of safety. Under normal conditions of operation (NO) and in case of violation of normal operation (VNO), the 
stresses in the housing do not exceed $110 \mathrm{MPa}$ for a group of stress categories $(\sigma)_{2}$ that take into account mechanical loads. According to preliminary estimates, the additional stresses from the decompression wave are negligible, and given that in accident situations the permissible stresses [14] are 1.4 times greater than normal operating conditions, the strength conditions are fulfilled with margin.

In the horizontal direction, the MCP housing is supported by three shock absorbers (GA), which are at an angle of $120^{\circ}$ and which have to take the dynamic and seismic loading. Generally, GA P-170 is used at domestic NPPs, which can handle up to 170 tonnes or 1,667 MN. Conservatively, we will assume that only two hydraulic shock absorbers will take the reactive force, then each of them will be loaded by:

$$
F^{\prime}=F / 2 \cdot \frac{1}{\cos 30^{\circ}}=F / 2 \cdot 2 / \sqrt{3} \approx 0.577 F .
$$

Using shown in Fig. $6 \mathrm{~b}$ reactive force and calculating the load on GA per (4), we obtain the value of $0.4 \mathrm{MN}$, which is much less than the permissible load on GA. Even when considering load combinations NO + SSE + PA, where SSE is the safety shutdown earthquake and PA is a project accident, the effort on one GA will not exceed 0.9 MN.

Consider the strength of the wheel and shaft. Fig. 7 shows a sketch of their connection, the torque is transmitted from the shaft to the impeller through a sleeve with involute slots $(m=5, z=32)$, the wheel is connected to the sleeve by three pressed pins $\varnothing 24.5$. The necessary dimensions for calculation are shown in Fig. 9.

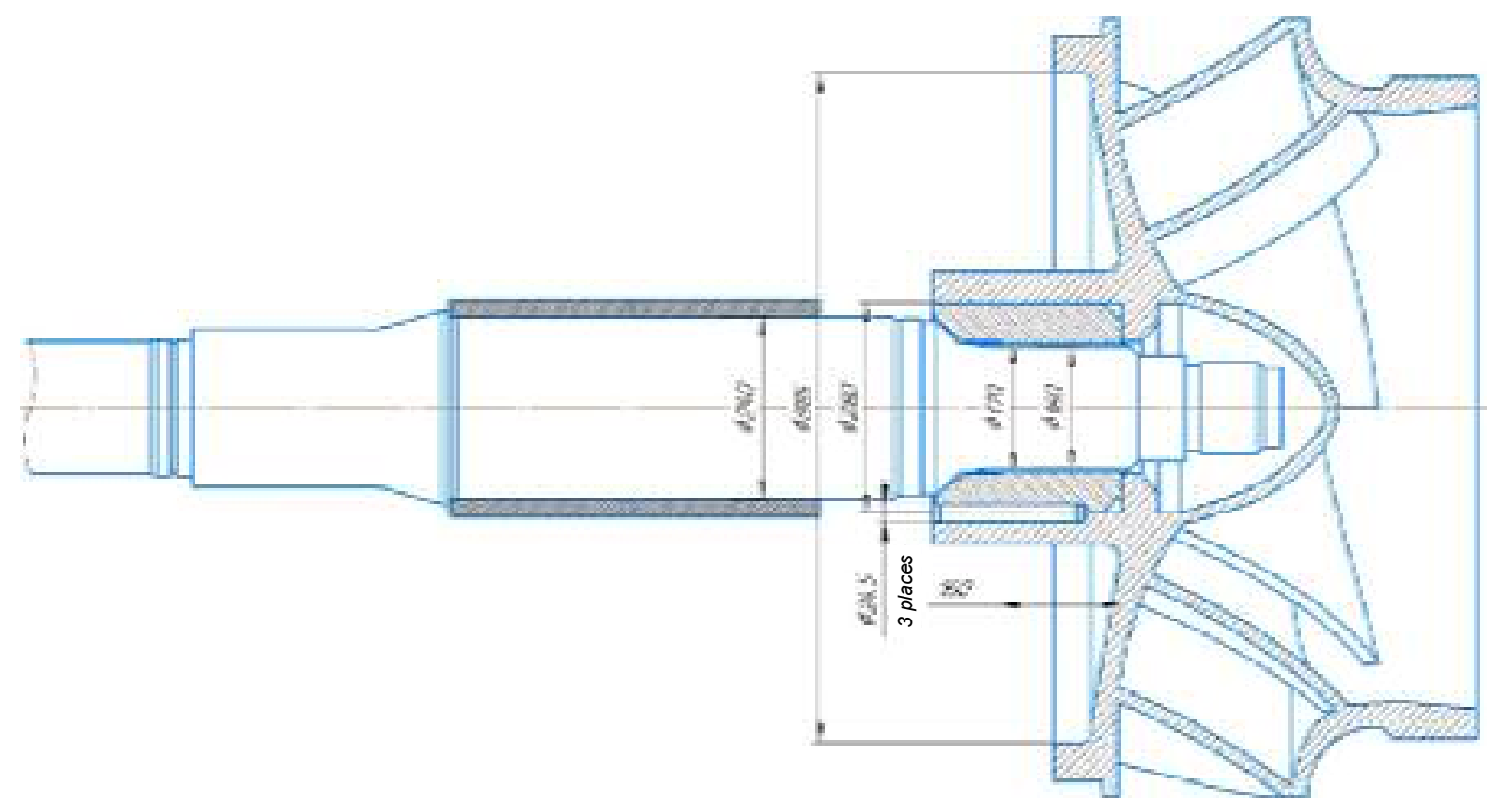

Fig. 9. Sketch of connecting a shaft to an impeller

To estimate the stresses in the impeller and the rotor, a finite-element model was created and previously obtained pressure for the MCP shaft jamming and MPA was used as a boundary condition. The results of the calculation are shown in Fig. 10. It can be seen that the impeller stresses are insignificant, with maximum local peak value of $337 \mathrm{MPa}$. Their use in cyclic strength estimation is inappropriate since, after these emergencies, the MCP internals will be inspected and repaired if necessary. The calculation of brittle strength is also unnecessary, since the impeller is made of austenitic steel. The only one possible mechanism of failure is the loss of bearing capacity when plastic hinges appear, i.e. viscous fracture. Because the stresses are highly local in nature and rapidly attenuate through the thickness of the blade wall, they are not dangerous and cannot cause impeller damage. 

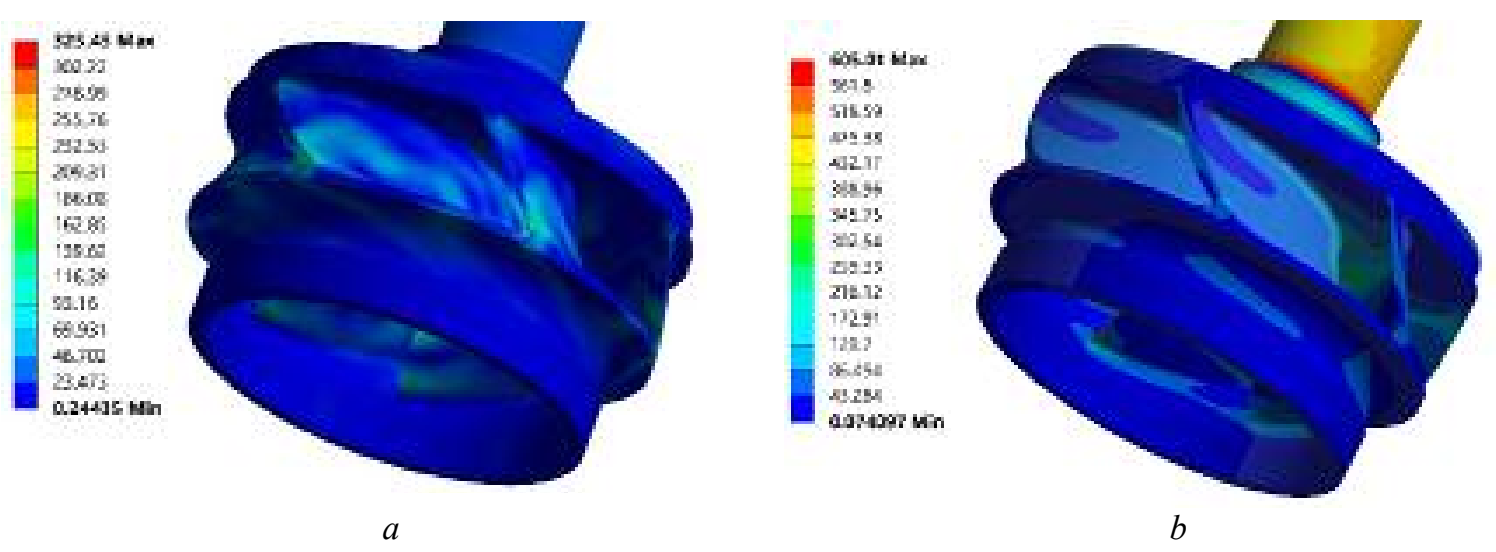

Fig. 10. Equivalent von Mises stresses in the MCP blades, MPa: jamming of the MCP (a), MPA (b)

The evaluation of the MCP's rotor strength should be performed taking into account both the tangent and the bending stresses. But, given that it is designed with a large margin of safety, more in the condition of rigidity than durability, the weaker link is the slot sleeve, which, moreover, is made of worse steel. In this case, the performance of the slotted connection should be evaluated in the absence of contact surfaces being bent:

$$
\sigma_{\text {bent }}=\frac{T}{\varphi \cdot F \cdot r}<[\sigma]_{b e n t}=220 \mathrm{MPa},
$$

where $\varphi=0.75$ - coefficient that takes into account the uneven load distribution between the slots;

$F=0.02 \mathrm{~m}^{2}-$ the area of the lateral surface of the slots;

$r=86 \mathrm{~mm}-$ the internal radius of the sleeve with slots.

According to the impeller calculation, the maximum dynamic torque during an MPA is 1204800 $\mathrm{Nm}$, and at jamming $42639 \mathrm{Nm}$, which causes stresses level around $90 \mathrm{MPa}$ and $970 \mathrm{MPa}$, respectively, i.e. the strength conditions (5) are met only for the MCP jamming.

With MPA, we have a considerable load thus the slot will fail not the impeller. The absence of criteria when calculating the MPA for the MCP internals, as well as the fact that after the MPA the equipment of the reactor installation will not be operated (in any case after the emergency the equipment will be fully inspected), makes it possible to extend the lifetime of all the MCP equipment.

Conclusions. Analyzing the initial dynamics and predicting the field of distributed parameters using system codes is practically impossible for the phenomena associated with the MCP shaft jamming or with the MPA.

To form the distributed values of the boundary conditions for the calculations on the strength of the MCP elements, a CFD model of the flow part of the pump was developed, which, within $5 \%$ deviation from the field measurements, makes it possible to predict the head pressure. In the case of a single-phase medium in the absence of local cavitation, the calculated CFD model of the flowing part of the MCP-195M enables to predict in the first approximation the initial dynamics of transients associated with a change in torque (shaft jamming) or with a change in loop resistance (MPA).

MCP jamming was modeled on the assumption of an abrupt torque change with two different variants of boundary conditions that take into account / do not take into account the change in the mass flow rate of the suction pipe. The dynamics of change in absolute pressure and velocity field at MPA (breaking the "cold thread"), were also predicted for two different variants of boundary conditions, among which the influence of the reactor is taken into account based on the results obtained in [3].

In both cases, the initial dynamics of the transition process is not qualitatively different for different variants of boundary conditions, respectively. To account for the compressibility of the coolant, a "compressible fluid method" is used, which is based on the Tate's equation. The estimation of the reac- 
tive force from the side of the pressure head of the MCP was estimated in the assumption of zero displacement of the pump housing in a zero-dimensional approximation.

It is shown that when the shaft is jammed there are conditions of incomplete water hammer, the through passage of the MCP is not overlapped, so the use of formulas of the complete water hammer is too conservative and leads to overestimation of stresses, both in the body elements of the MCP and in the MCP internals.

Strength calculations of the most loaded elements of the MCP were carried out: the housing, shock absorbers, impeller, rotor. In terms of dynamic stresses, the most dangerous is the maximum design accident. The results of the calculations indicate that structural integrity conditions are fulfilled, apart from the maximum design accident for the impeller connecting elements. At the same time, it should be noted that there are no calculation criteria for dynamic loads of the rotor and the impeller.

\section{Література}

1. Безруков Ю.А., Лисенков Е.А., Селезнев А.В. Анализ возможности гидроударов в первом контуpe реакторов ВВЭР. ОАО ОКБ «Гидропресс», г. Подольск, Россия. URL: https://studylib.ru/doc/ 767399/analiz-vozmozhnosti-gidroudarov-v-pervom-konture.

2. ANSYS Fluent User's Guide. 2013. URL: http://www.pmt.usp.br/academic/martoran/ notasmodelosgrad/ANSYS\%20Fluent\%20Users\%20Guide.pdf.

3. Dubyk Y., Filonov V., Ishchenko O., Oryniak I., Filonova Y., Dynamic assessment of the core barrel during loss of coolant accident. Proceedings of the ASME 2018 Pressure Vessels \& Piping ConferencePVP2018-84762, July 15-20, Prague, Czech Repuplic.

4. Near Wall Modeling - Turbulence Modeling Using Ansys CFX.

5. Пугачев П.В., Свобода Д.Г., Жарковский А.А. Расчет вязкого течения в лопастных гидромашинах с использованием пакета ANSYS CFX. Санкт - Петербург : Издательство Политехнического университета, 2016. $120 \mathrm{c}$.

6. Menter F. CFD Best Practice Guidelines for CFD Code Validation for Reactor-Safety Applications, EVOL-ECORA-D01. 2002.

7. Ломакин А.А. Центробежные и осевые насосы. «Машиностроение», 1966. 364 с.

8. Лагвинов С.А., Безруков Ю.А., Драгунов Ю.Г. Экспериментальное обоснование теплогидравлической надежности реакторов ВВЭР. Москва : ИКЦ «Академкнига», 2004. 255 с.

9. Волков В.Ю., Голибродо Л.А., Крутиков А.А., Кудрявцев О.В., Надинский Ю.Н., Скибин А.П. Разработка CFD модели ГЦНА. Суперкомпьютерные дни в России 2016. 2016. ОАО ОКБ «Гидропресс», г. Подольск, Россия. С. 556-565.

10. Bestion D. Applicability of two-phase CFD to nuclear reactor thermalhydraulics andelaboration of Best Practice Guidelines. Intern. J. Nuclear Engineering and Design. 2012. 253. P 311-321.

11. Rahgoshay M., Hashemi-Tilehnoee M. Pressure distribution in the containment of VVER-1000 during the first seconds of large break LOCA. Intern. J. Progress in Nuclear Energy. 2016. 88. P 211-217.

12. BARC/1998/E/032, Fluid Structure Interaction Studies on Acoustic Load Response of Light Water Nuclear Reactor Core Internals Under Blowdown Condition. Bhabha Atomic Research Centre. 1998. Mumbai, India.

13. Alamgir Md., Lienhard J.H. Correlation of Pressure Undershoot during Hot-Water Depressurization. Journal of Heat Transfer. 1981. Vol. 103. Р. 53-55.

14. Нормы расчета на прочность оборудования и трубопроводов для АЭС. Москва : Энергоатомиздат, 1989. 525 с.

\section{References}

1. Bezrukov, Yu.A., Lisenkov, E.A., \& Seleznev, A.V. Analysis of water hammer possibility in the primary circuit of VVER reactors. OKB GIDROPRESS, Podolsk, Russia. Retrieved from: https://studylib.ru/doc/767399/analiz-vozmozhnosti-gidroudarov-v-pervom-konture.

2. ANSYS Fluent User's Guide. (2013). Retrieved from: http://www.pmt.usp.br/academic/martoran/ notasmodelosgrad/ANSYS\%20Fluent\%20Users\%20Guide.pdf.

3. Dubyk, Y., Filonov, V., Ishchenko, O., Oryniak, I., \& Filonova, Y. (2018). Dynamic assessment of the core barrel during loss of coolant accident. Proceedings of the ASME 2018 Pressure Vessels \& Piping Conference-PVP2018-84762, July 15-20, Prague, Czech Repuplic.

4. Near Wall Modeling - Turbulence Modeling Using Ansys CFX. 
5. Pugachev, P.V., Svoboda, D.G., \& Zharkovskii, A.A. (2016). Calculation of viscous flow in blade hydraulic machines using ANSYS CFX. St. Petersburg: Publishing house of the Polytechnic University.

6. Menter, F. (2002). CFD Best Practice Guidelines for CFD Code Validation for Reactor-Safety Applications, EVOL-ECORA-D01.

7. Lomakin, A.A. (1966). Centrifugal and axial pumps. Mashinostroenie.

8. Lagvinov, S.A., Bezrukov, Yu.A., \& Dragunov, Yu.G. (2004). Experimental justification of VVER reactors thermal-hydraulic reliability. Moscow: IKTs Akademkniga.

9. Volkov, V. Yu., Golibrodo, L.A., Krutikov, A.A., Kudryavtsev, O.V., Nadinskii, Yu.N., \& Skibin, A.P. (2016). MCPAs CFD model development. Supercomputer days in Russia 2016. Podolsk: OKB GIDROPRESS, Russia.

10. Bestion, D. (2012). Applicability of two-phase CFD to nuclear reactor thermalhydraulics andelaboration of Best Practice Guidelines. Intern. J. Nuclear Engineering and Design, 253, 311-321.

11. Rahgoshay, M., \& Hashemi-Tilehnoee, M. (2016). Pressure distribution in the containment of VVER1000 during the first seconds of large break LOCA. Intern. J. Progress in Nuclear Energy, 88, 211-217.

12. BARC/1998/E/032. (1998). Fluid Structure Interaction Studies on Acoustic Load Response of Light Water Nuclear Reactor Core Internals Under Blowdown Condition. Bhabha Atomic Research Centre, Mumbai, India.

13. Alamgir, Md., \& Lienhard, J.H. (1981). Correlation of Pressure Undershoot during Hot-Water Depressurization. Journal of Heat Transfer, 103, 53-55.

14. Strength calculation standards for NPP equipment and pipelines. (1989). Moscow: Energoatomizdat.

Філонов Владислав Віталійович; Filonov Vladyslav, ORCID: https://orcid.org/0000-0001-8123-026X

Дубик Ярослав Романович; Dubyk Yaroslav, ORCID: https://orcid.org/0000-0002-4327-412X

Лук'яненко Костянтин Михайлович; Lukianenko Kostiantyn, ORCID: https://orcid.org/0000-0003-1240-7425

Received September 02, 2019

Accepted November 03, 2019 